\title{
PENINGKATAN KETERAMPILAN GURU DALAM PEMBUATAN MEDIA PEMBELAJARAN BERBASIS LECTORA INSPIRE 17 MELALUI WORKSHOP DI SMK NEGERI 1 PAJANGAN
}

\author{
Pariyana \\ SMK Negeri 1 Pajangan Bantul \\ pariyana72@yahoo.co.id
}

\begin{abstract}
Abstrak: Penelitian ini bertujuan untuk meningkatkan keterampilan guru SMK Negeri 1 Pajangan Kabupaten Bantul dalam pembuatan media pembelajaran berbasis Lectora Inspire 17 melalui workshop. Jenis penelitian ini adalah penelitian tindakan sekolah dengan subyek penelitian adalah guru PNS SMK Negeri 1 Pajangan yang berjumlah 31 orang yaitu 14 guru mata pelajaran Normatif Adaptif, 5 guru Kria Kreatif Kayu Rotan, 6 guru Rekayasa Perangkat Lunak dan 6 guru Desain Pemodelan dan Informasi Bangunan. Penelitian ini terdiri dari dua siklus, untuk setiap siklus melakukan tahap perencanaan, pelaksanaan, pengamatan dan refleksi. Teknik pengumpulan data dengan triangulasi melalui observasi kegiatan workshop, observasi keaktifan guru, dan penilaian media pembelajaran yang dihasilkan. Data yang diperoleh dianalisis dengan analisis deskriptif. Hasil penelitian ini menunjukkan tingkat keterampilan guru dengan kriteria terampil sejumlah 25,81\% (8 guru), siklus I meningkat menjadi 61,29\% (19 guru), dan pada siklus II mengalami peningkatan menjadi 87,10\% (27 guru), sehingga terjadi peningkatan antara kondisi pra tindakan dan siklus I sebesar 35,48\% dan antara siklus I dan siklus II terjadi peningkatan sebesar $25,81 \%$. Berdasarkan hasil analisis data dapat disimpulkan bahwa kegiatan workshop dapat meningkatkan keterampilan guru SMK Negeri 1 Pajangan dalam pembuatan media pembelajaran berbasis Lectora Inspire 17.
\end{abstract}

Kata kunci: keterampilan, workshop, media pembelajaran

\section{IMPROVING TEACHER'S ABILITY IN MAKING INSTRUCTIONAL MEDIA BY USING LECTORA INSPIRE 17 THROUGH WORKSHOP AT SMK NEGERI 1 PAJANGAN}

\begin{abstract}
This study aims to improve teachers' commitment and skil at SMK Negeri 1 Pajangan Kabupaten Bantul in making instructional media Lectora Inspire 17 through workshop activities. This research is school action research with the subjects of this research were PNS teachers of SMK Negeri 1 Pajangan and the numbers are 31 (thirty one) teachers. They were 14 (fourteen) teachers of Normatif Adaptif, 5 (five) teachers of KKKR, 6 (six) teachers of RPL, and 6 (six) teachers of DPIB. This research consists of two cycles, each cycle carried out stages of planning, implementation, observation and reflection. The data collection technique used triangulasi through observing workshop activities, teachers' activities, and the evaluation of teaching media. The data was analyzed using descriptive analysis. This result shown that the degree of teachers' skills with competen were 25,81\% (8 teachers), Cycle I increased 61,29\% (19 teachers), and Cycle II increased 87,10\% (27 teachers), so there was increasing between pre cycle and Cycle I 35,48\%, between cycle I and cycle II increased 25,81\%. Based on data analysis could be concluded that workshop activities could improve teachers' skills at SMK Negeri 1 Pajangan in making instructional media Lectora Inspire 17.
\end{abstract}

Keywords: skills, workshop, and instructional media

\section{PENDAHULUAN}

Tugas pendidik pada pendidikan menengah khususnya Sekolah Menengah Kejuruan (SMK) adalah membantu siswa didik mencapai kompetensi secara maksimal. Agar mempermudah guru dalam mencapai kompetensi inti hendaknya sebelum melaksanakan pembelajaran guru membuat Rencana Pelaksanaan Pembelajaran (RPP). Dalam RPP tertuang antara lain kompetensi dasar, tujuan, indicator pencapaian kompetensi, materi, sumber belajar dan media pembelajaran. Agar pembelajaran menjadi menarik dan bermakna sangat diperlukan media pembelajaran. Guru dapat menggunakan media yang biasa digunakan sebagai perantara dalam menyampaikan pesan kepada siswa. Media pembelajaran mempunyai peranan yang sangat penting dalam kegiatan pendidikan dan pelatihan. Media pembelajaran yang dimanfaatkan dapat membantu mempermudah pembelajaran secara efektif dan efisien.

Beberapa contoh media yang biasa digunakan dalam pendidikan misalnya media proyeksi dan non proyeksi, media audio, multi media yang berdasarkan komputer dan hypermedia, internet, serta media komunikasi masa seperti radio dan televisi yang dipakai untuk 
pengajaran jarak jauh. Kesemuanya itu dianggap sebagai media instruksional jika media tersebut membawa pesan untuk mencapai tujuan instruksional. Pada saat ini banyak program aplikasi media pembelajaran interaktif yang dapat digunakan secara gratis.

SMK Negeri 1 Pajangan memiliki guru sebanyak 31 guru yang terdiri dari 24 PNS, 5 guru CPNS dan 3 guru tidak tetap dengan rincian 14 guru NA, 7 guru RPL, 5 guru DPIB, dan 5 guru K3R. Semua guru memiliki kemampuan dalam menggunakan Komputer khususnya program office dan sebagian besar guru sudah memiliki laptop. Berdasarkan supervisi guru yang dilaksanakan semester 1 maupun semester 2 tahun pelajaran 2018/2019, diperoleh hasil bahwa sebanyak 23 guru belum menggunakan media pembelajaran interaktif (berbasis program aplikasi) dalam kegiatan belajar mengajar. Penyebabnya adalah minimnya pengetahuan tentang berbagai program aplikasi media pembelajaran, belum terampil dalam pembuatan media pembelajaran, dan rendahnya pemanfaatan fasilitas sekolah.

Untuk meningkatkan keterampilan guru dalam membuat media pembelajaran perlu dilakukan tindakan melalui workshop. Workshop adalah suatu pertemuan ilmiah untuk menghasilkan karya nyata melalui proses pelatihan untuk meningkatkan pengetahuan, sikap, keterampilan dan kemampuan guru. Dengan kegiatan workshop, guru akan mendapatkan pengetahuan dan melakukan praktik langsung membuat media pembelajaran tahap demi tahap. Guru diharapkan berperan aktif dalam mengikuti kegiatan workshop. Dalam membuat media pembelajaran, guru dibimbing oleh pemateri dan dapat bekerja sama dengan peserta yang lain. Tujuan dari workshop ialah untuk memperoleh informasi melalui pengalaman langsung dan saling menyampaikan informasi, dilakukan untuk menghasilkan media pembelajaran yang bermanfaat bagi kegiatan belajar mengajar.

Berdasarkan latar belakang dan identifikasi masalah tersebut di atas, maka rumusan masalah dalam penelitian ini adalah (1) Apakah melalui workshop dapat meningkatkan keterampilan guru dalam pembuatan media pembelajaran berbasis Lectora Inspire 17? (2) Bagaimana langkahlangkah peningkatan keterampilan guru dalam pembuatan media pembelajaran berbasis Lectora Inspire 17 melalui workshop di SMK Negeri 1 Pajangan?

Penelitian ini dilakukan dengan tujuan untuk meningkatan keterampilan guru SMK Negeri 1 Pajangan dalam pembuatan media pembelajaran berbasis Lectora Inspire 17 melalui workshop.
Keterampilan menurut Widia Pekerti (2012: 10) merupakan kemampuan menggunakan alatalat dan media ungkap penting dan sangat dibutuhkan karena dapat mempermudah dan memperlancar dalam mengungkapkan perasaan. Untuk meningkatkan keterampilan harus diberikan latihan-latihan pengenalan alat dan media serta teknik penggunaanya.

Dalam situasi pembelajaran di SMK terdapat pesan-pesan yang harus dikomunikasikan. Pesanpesan tersebut disampaikan oleh guru kepada siswa melalui suatu media dengan menggunakan prosedur pembelajaran tertentu yang disebut metode. Media juga sering diartikan teknologi pembawa pesan yang dapat dimanfaatkan untuk kepentingan pembelajaran, sarana fisik untuk menyampaikan isi, sarana komunikasi dalam bentuk cetak maupun pandang dengar termasuk teknologi perangkatnya.

Menurut Arif S. Sadiman dkk (2013: 7) media adalah segala sesuatu yang dapat digunakan untuk menyalurkan pesan dari pengirim ke penerima sehingga merangsang pikiran, perasaan, perhatian, dan minat sedemikian rupa sehingga proses belajar terjadi. Keuntungan penggunaan multimedia dalam pembelajaran diantaranya dapat meningkatkan kemampuan siswa dalam memahami suatu konsep abstrak dengan lebih mudah, selain itu juga penggunaan media komputer dalam bentuk multimedia dapat memberikan kesan yang positif kepada guru karena dapat membantu guru menjelaskan isi pelajaran kepada pelajar, menghemat waktu dan meningkatkan motivasi siswa dalam belajar.

Lectora Inspire 17 adalah sebuah program komputer yang merupakan tool (alat) pengembangan belajar elektronik (e-learning), dikembangkan oleh Perusahaan Trivantis Corporation. Pendirinya adalah Timothy D. Loudermilk di Cincinnati, Ohio, Amerika tahun 1999. Lectora inspire 17 merupakan salah satu program aplikasi yang dapat digunakan untuk membuat presentasi maupun media pembelajaran. Keunggulan lectora inspire 17 sangat user friendly (mudah digunakan) dalam pembuatan media pembelajaran. Lectora inspire 17 memang awalnya diciptakan untuk kebutuhan e-learning. Lectora inspire 17 dapat digunakan untuk kebutuhan pembelajaran baik secara online maupun offline yang dapat dibuat dengan cepat dan mudah. Lectora inspire 17 menyediakan template yang siap digunakan untuk memasukkan materi pembelajaran, selain itu di dalam Library Lectora inspire sudah terdapat banyak gambar, animasi, karakter animasi yang dapat kita gunakan secara langsung. 
Workshop adalah suatu pertemuan ilmiah dalam bidang sejenis (pendidikan) untuk menghasilkan karya nyata. Terdapat beberapa jenis workshop berdasarkan sifatnya menurut Rosmaryanti (2010), yaitu workshop bersifat mengikat, dan bebas atau tidak mengikat. Prosedur yang dilakukan dalam pelaksanaan workshop mencakup beberapa hal, diantaranya (1) merumuskan tujuan untuk memperoleh output/hasil akhir yang akan dicapai, (2) merumuskan pokok - pokok masalah yang akan dibahas secara rinci yang dimaksudkan untuk mempermudah proses berjalannya kegiatan, serta (3) menentukan prosedur pemecahan masalah.

\section{METODE PENELITIAN Jenis Penelitian}

Penelitian yang dilakukan adalah Penelitian Tindakan Sekolah. Desain siklus dalam penelitian ini terdiri dari permasalaha, rencana tindakan, pelaksanaan tindakan, observasi, analisis data, dan refleksi (Aqib Z, Amrullah A, 2017).

\section{Waktu Penelitian dan Tempat Penelitian}

Penelitian ini dilaksanakan pada tahun 2019, dalam waktu 5 bulan (April sampai dengan Agustus 2019). Dari hasil supervisi guru kemudian dilaksanakan workshop pembuatan media pembelajaran berbasis Lectora Inspire 17, yaitu siklus I dilaksanakan hari Rabu, tanggal 15 Mei 2019 dan hari Senin, tanggal 20 Mei 2019. Kemudian pelaksanaan siklus II dilaksanakan hari Rabu, tanggal 10 Juli 2019, hari Senin, 15 Juli 2019, dan hari Selasa, 16 Juli 2019. Penelitian ini dilaksanakan di SMK Negeri 1 Pajangan yang beralamat di Pajangan, Triwidadi, Pajangan, Bantul, Yogyakarta.

\section{Subyek Penelitian}

Subyek penelitian ini adalah guru SMK Negeri 1 Pajangan yang terdiri dari 31 orang guru, 18 perempuan dan 13 laki-laki, 25 orang memiliki kualifikasi pendidikan S1, 6 orang kualifikasi pendidikan S2, dan 31 guru tersebut mengampu berbagai mata pelajaran dengan rincian sebagai berikut: 15 guru Normatif Adaptif, 6 guru RPL, 6 guru DPIB, dan 4 guru K3R.

\section{Variabel Penelitian}

Workshop yang digunakan pada proses atau tahapan-tahapan yang dilalui guru untuk memperoleh suatu konsep yang benar pada cara pembuatan media pembelajaran berbasis Lectora Inspire 17, variabel yang diamati ditinjau dari 1) Aspek keaktifan guru, meliputi keaktifan yang diukur melalui pengamatan guru pada saat melakukan pembuatan media pembelajaran. 2) Aspek keterampilan guru, meliputi keterampilan yang diukur melalui penilaian hasil media pembelajaran yang telah dibuat (kesesuaian materi dan kelengkapannya).

\section{Tahap Perencanaan Tindakan}

Secara rinci langkah-langkah kegiatan yang dilaksanakan pada tahap perencanaan adalah sebagai berikut:

1) Merancang langkah-langkah workshop (TOR), menentukan program aplikasi, dan bahan ajar.

2) Merancang instrumen penilaian media pembelajaran, lembar observasi kegiatan workshop, lembar observasi keaktifan guru sebagai pedoman dalam melaksanakan pengamatan tindakan siklus I dan siklus II.

3) Membuat undangan untuk guru sebagai peserta workshop.

4) Menyiapkan program aplikasi, media, laboratorium komputer dan perlengkapannya sebagai tempat workshop siklus I dan siklus II.

5) Menyiapkan observer dari teman sejawat guru.

Langkah-langkah yang diperlukan dalam tindakan sekolah yaitu guru diberi bahan ajar dan program aplikasi Lectora Inspire 17, kemudian setiap guru menginstal program aplikasi Lectora Inspire 17 pada komputer masing-masing. Pemateri menerangkan tentang langkah - langkah pembuatan media pembelajaran berbasis Lectora Inspire 17. Kemudian guru melakukan praktik membuat media pembelajaran berbasis Lectora Inspire 17 dengan mengikuti langkah-langkah yang disampaikan. Masing-masing guru melanjutkan pembuatan media pembelajaran dengan kerja individu. Secara terperinci langkah-langkah pelaksanaan tindakan seperti tabel di bawah ini. 
Tabel 1. Langkah-langkah pelaksanaan tindakan siklus I, pada pertemuan pertama

\begin{tabular}{|c|c|c|c|}
\hline No & Kegiatan Pemateri & Kegiatan Guru & Waktu \\
\hline 1. & $\begin{array}{l}\text { A. Kegiatan Pendahuluan } \\
\text { - Mengucapkan salam dan doa } \\
\text { - Menjelaskan tujuan workshop menggunakan } \\
\text { power point } 1 \\
\text { - Membagikan program aplikasi Lectora Inspire } 17 \\
\text { - Memandu menginstal program aplikasi Lectora } \\
\text { Inspire } 17 \text { pada komputer } \\
\text { - Menjelaskan prosedur praktik pembuatan media } \\
\text { pembelajaran }\end{array}$ & $\begin{array}{l}\text { - Menjawab salam dan doa } \\
\text { - Memperhatikan penjelasan pemateri } \\
\text { - Mengcopi program aplikasi Lectora } \\
\text { Inspire } 17 \\
\text { - Menginstal program aplikasi } \\
\text { Lectora Inspire } 17 \text { pada komputer } \\
\text { - Mendengarkan dan bertanya bila } \\
\text { belum mengerti }\end{array}$ & $40^{\prime}$ \\
\hline 2. & $\begin{array}{l}\text { B. Kegiatan Inti } \\
\text { Eksplorasi } \\
\text { - Menyajikan materi manfaat, cara } \\
\text { menggunakan, dan keuntungan program } \\
\text { aplikasi Lectora Inspire } 17 \text { mengunakan power } \\
\text { point } 2 \\
\text { - Menyajikan materi pengenalan dasar Lectora } \\
\text { Inspire } 17 \text { mengunakan power point } 3 \\
\text { - Menyajikan materi manfaat Chapter } \\
\text { mengunakan power point } 4 \\
\text { - Mengamati keaktifan guru } \\
\text { - Menjelaskan pada guru yang bertanya secara } \\
\text { individu, sesekali mengendalikan keadaan } \\
\text { kegiatan workshop bila perlu } \\
\text { Elaborasi } \\
\text { - Mengkoordinir praktik pembuatan media } \\
\text { pembelajaran } \\
\text { - Bersama dengan observer, mengamati dan } \\
\text { menilai aspek keterampilan yang dilakukan } \\
\text { guru } \\
\text { - Menjelaskan pada guru yang bertanya secara } \\
\text { individu, sesekali mengendalikan keadaan } \\
\text { kegiatan workshop bila perlu }\end{array}$ & $\begin{array}{l}\text { - Melakukan praktik membuat media } \\
\text { pembelajaran, dan bertanya bila } \\
\text { belum mengerti }\end{array}$ & $40^{\prime}$ \\
\hline 3. & $\begin{array}{l}\text { C. Kegiatan Akhir } \\
\text { - Menjelaskan kegiatan workshop yang akan } \\
\text { datang } \\
\text { - Mengakhiri workshop dengan doa dan salam }\end{array}$ & $\begin{array}{l}\text { - Memperhatikan informasi kegiatan } \\
\text { workshop yang akan datang } \\
\text { - Berdoa dan menjawab salam }\end{array}$ & $15^{\prime}$ \\
\hline & Jumlah & & 180' \\
\hline
\end{tabular}

Dari tabel di atas pada pertemuan pertama, setiap guru melakukan praktik pembuatan media pembelajaran secara individu sampai pada materi 3. Pada pertemuan ke-2 setiap guru melanjutkan praktik pembuatan media pembelajaran secara individu pada materi 4, 5, dan 6. Langkah-langkah pengimplementasian tindakan siklus I pada pertemuan ke-2 dapat dilihat pada tabel 2 di bawah ini: 
Tabel 2. Langkah-langkah pelaksanaan tindakan siklus I, pada pertemuan ke-2

\begin{tabular}{|c|c|c|c|}
\hline No & Kegiatan Pemateri & Kegiatan Guru & Waktu \\
\hline 1. & $\begin{array}{l}\text { A. Kegiatan Pendahuluan } \\
\text { - Mengucapkan salam dan doa } \\
\text { - Menjelaskan prosedur praktik pembuatan media } \\
\text { pembelajaran }\end{array}$ & $\begin{array}{l}\text { - Menjawab salam dan doa } \\
\text { - Mendengarkan dan bertanya bila } \\
\text { belum mengerti }\end{array}$ & $15^{\prime}$ \\
\hline 2. & $\begin{array}{l}\text { B. Kegiatan Inti } \\
\text { Eksplorasi } \\
\text { - Menyajikan materi memasukkan objek (Teks, } \\
\text { Gambar, Audio, Animasi, dan Video) } \\
\text { mengunakan power point } 5 \\
\text { - Menyajikan materi pembuatan soal atau kuis } \\
\text { mengunakan power point } 6 \\
\text { - Menyajikan materi cara dokumentasi dan } \\
\text { publikasi mengunakan power point } 7 \\
\text { - Mengamati keaktifan guru } \\
\text { - Menjelaskan pada guru yang bertanya secara } \\
\text { individu, sesekali mengendalikan keadaan } \\
\text { kegiatan workshop bila perlu } \\
\text { Elaborasi } \\
\text { - Mengkoordinir praktik pembuatan media } \\
\text { pembelajaran } \\
\text { - Bersama dengan observer, mengamati dan } \\
\text { menilai aspek keterampilan yang dilakukan } \\
\text { guru } \\
\text { - Menjelaskan pada guru yang bertanya secara } \\
\text { individu, sesekali mengendalikan keadaan } \\
\text { kegiatan workshop bila perlu }\end{array}$ & $\begin{array}{l}\text { - Mendengarkan, melakukan praktik } \\
\text { membuat media pembelajaran, dan } \\
\text { bertanya bila belum mengerti }\end{array}$ & $70^{\prime}$ \\
\hline 3. & $\begin{array}{l}\text { C. Kegiatan Akhir } \\
\text { - Memberi lembar observasi kegiatan workshop } \\
\text { - Menjelaskan kegiatan workshop yang akan } \\
\text { datang } \\
\text { - Mengakhiri workshop dengan doa dan salam }\end{array}$ & $\begin{array}{l}\text { - Mengisi/menjawab lembar observasi } \\
\text { kegiatan workshop } \\
\text { - Memperhatikan informasi kegiatan } \\
\text { workshop yang akan datang } \\
\text { - Berdoa dan menjawab salam }\end{array}$ & $\begin{array}{l}20{ }^{\prime} \\
10\end{array}$ \\
\hline
\end{tabular}

Akhir dari tindakan siklus I dianalisa lembar observasi kegiatan workshop, keaktifan guru, penilaian produk, dan refleksi yang akan digunakan sebagai perbaikan di siklus II.

\section{Siklus II}

Setelah Siklus I selesai, tahapan siklus II mengikuti tahapan kerja siklus I, dalam hal ini rencana tindakan siklus II disusun berdasarkan hasil refleksi dan observasi pada siklus I melalui perbaikan yang telah disesuaikan dengan permasalahan pada siklus I. Apabila masih terdapat permasalahan yang baru maka dilanjutkan ke siklus III. Pada dasarnya pelaksanaan siklus II sama dengan siklus I, hanya pada siklus II ini ada perubahan sesuai dengan kelemahan dari siklus I sehingga diharapkan pada siklus II ini terjadi peningkatan keterampilan guru dalam pembuatan media pembelajaran. Pada siklus II ini materi yang diberikan adalah tentang membuat media pembelajaran berbasis Lectora Inspire 17.

\section{Instrumen Penelitian}

Data dalam penelitian ini berbentuk data kualitatif dan kuantitatif yang memuat tentang keterampilan guru dalam pembuatan media pembelajaran berbasis Lectora Inspire 17 melalui workshop. Sumber data dikumpulkan dengan menggunakan 3 macam instrumen yaitu: 1) Lembar observasi kegiatan workshop. Observasi kegiatan workshop dilakukan untuk memperoleh data pelaksanaan/langkah-langkah workshop. 2) Lembar observasi keatifan guru, dilakukan untuk memperoleh data keaktifan guru dalam mengikuti kegiatan workshop. 3) Lembar penilaian media pembelajaran, dilakukan untuk memperoleh data keterampilan guru dalam pembuatan media pembelajaran berbasis Lectora Inspire 17. 


\section{Pengumpulan Data}

Sumber data penelitian ini berasal dari kegiatan workshop pembuatan media pembelajaran berbasis Lectora Inspire 17 di SMK N 1 Pajangan Bantul. Jenis data terdiri dari: 1) Data Kualitatif adalah data hasil observasi kegiatan workshop dan hasil observasi keaktifan guru. 2) Data Kuantitatif adalah data hasil penilaian media pembelajaran.

Cara memperoleh data yaitu: 1) Data pelaksanaan/langkah-langkah workshop diperoleh ketika guru sudah selesai mengikuti wokshop dengan menggunakan instrumen berupa lembar observasi kegiatan workshop. Lembar observasi ini diisi oleh guru (peserta workshop) dengan cara memberikan rentang skor antara 1 sampai 4 untuk masing-masing tahap kegiatan workshop. 2) Data keaktifan guru diperoleh ketika guru mengikuti kegiatan workshop dengan menggunakan instrumen berupa lembar observasi keaktifan guru. Lembar observasi ini diisi oleh observer dengan cara memberikan rentang skor antara 1 sampai 4 untuk masing-masing indikator keaktifan guru dalam mengikuti kegiatan workshop. 3) Keterampilan guru diperoleh ketika guru telah menyelesaikan pembuatan media pembelajaran dengan menggunakan instrumen berupa lembar penilaian media pembelajaran. Lembar penilaian ini diisi oleh observer dengan cara memberikan rentang skor antara 1 sampai 4 untuk masing-masing indikator media pembelajaran berbasis Lectora Inspire 17.

\section{Analisis Data}

Data observasi kegiatan workshop, dianalisis dengan menggunakan rumus:

$$
\mathrm{KW}=\frac{\text { Jumlah skor yang diperoleh }}{\text { jumlah Skor Tertinggi }} \times 100 \%
$$

Mengkategorikan nilai akhir ke dalam tingkatan

$\begin{array}{ll}91-100 & : \text { Amat Baik } \\ 76-90 & \text { : Baik } \\ 61-75 & \text { : Cukup } \\ 51-60 & \text { : Sedang } \\ <51 & \text { : Kurang }\end{array}$

Data keaktifan guru, dianalisis menggunakan rumus:

$$
\mathrm{KG}=\frac{\text { Jumlah skor yang diperoleh }}{\text { Jumlah Skor Tertinggi }} \times 100
$$

Mengkategorikan nilai akhir ke dalam tingkatan

$$
\begin{array}{ll}
91-100 & : \text { Amat Baik } \\
76-90 & \text { : Baik } \\
61-75 & \text { : Cukup } \\
51-60 & \text { : Sedang } \\
<51 & \text { : Kurang }
\end{array}
$$

Data keterampilan guru, dianalisis menggunakan rumus:

$$
\mathrm{P}=\frac{\text { Jumlah skor yang diperoleh }}{\text { Jumlah skor Tertinggi }} \mathrm{X} 100
$$

Mengkategorikan nilai akhir ke dalam tingkatan

$$
\begin{array}{ll}
91-100 & \text { : Amat Baik } \\
76-90 & \text { : Baik } \\
61-75 & \text { : Cukup } \\
51-60 & \text { : Sedang } \\
<51 & \text { : Kurang }
\end{array}
$$

\section{Indikator Keberhasilan}

Sebagai indikator keberhasilan yang di capai guru dalam penelitian ini adalah sekurang-kurangnya $80 \%$ guru terampil membuat media pembelajaran berbasis Lectora Inspire 17 dengan kategori baik (skor minimal 76), juga ditandai dengan kegiatan workshop dilaksanakan secara baik (skor minimal 76) serta sekurang-kurangnya $75 \%$ Guru aktif mengikuti kegiatan workshop.

\section{HASIL DAN PEMBAHASAN}

\section{Hasil/Dampak Pengimplementasian Tindakan}

Berdasarkan hasil observasi pada pengimplementasian siklus I dan II, pelaksanaan kegiatan workshop, keaktifan guru dan penilaian media pembelajaran diakhir workshop, diperoleh hasil sebagai berikut:

\section{1) Pelaksanaan Kegiatan Workshop}

Pelaksanaan kegiatan workshop pembuatan media pembelajaran pada siklus I dan siklus II berjalan baik (Skor minimal 76). Tabel 3 di bawah ini menunjukkan peningkatan skor kegiatan workshop.

Tabel 3. Peningkatan Kegiatan Workshop

\begin{tabular}{clccc}
\hline No & Kegiatan Workshop & Skor Terendah & Skor Tertinggi & Skor Rata-rata \\
\hline 1. & Siklus I & 76,56 & 82,81 & 80,34 \\
2. & Siklus II & 81,25 & 87,49 & 85,18 \\
\hline
\end{tabular}

Berdasarkan tabel 3 di atas dapat dilihat bahwa kegiatan workshop mengalami peningkatan, pada siklus I skor terendah 76,56 sedangkan skor ratarata 80,34. Kondisi ini terjadi karena skor di atas
80,00 sebanyak 17 orang dan skor di bawah 80,00 sebanyak 14 orang. Hal ini menunjukkan workshop pada siklus I semua guru telah menilai bahwa workshop dilaksanakan dengan baik (skor 
minimal 76), namun masih bisa ditingkatkan. Kegiatan workshop pada siklus I sudah melakasanakan langkah- langkah workshop yaitu perencanaan, pelaksanaan dan evaluasi. Masih ada beberapa perbaikan yang perlu dilakukan pada siklus II, yaitu memberikan motivasi kepada peserta, penambahan waktu dan pembentukan kelompok guru yang beranggota 5-7 orang dengan satu fasilitator. Pada siklus II skor terendah 81,25 sedangkan skor rata-rata 85,18. Kondisi ini menunjukkan bahwa semua guru telah menilai kegiatan workshop dengan skor hampir sama. Terjadi Peningkatan skor rata-rata kegiatan workshop dari siklus I ke siklus II sebesar 4,84. Kondisi ini menunjukkan bahwa perbaikan pada siklus II telah berhasil memperbaiki kegiatan workshop. Keberhasilan kegiatan workshop dinyatakan dengan skor minimal 76 dan sudah tercapai pada siklus II dengan skor 85,18 (Baik). Dari tabel 3 di atas dapat ditampilkan keberhasilan kegiatan workshop pembuatan media pembelajaran berbasis Lectora Inspire 17 pada siklus I dan siklus II sebagai diagram batang di bawah ini.

\section{Tingkat Keberhasilan}

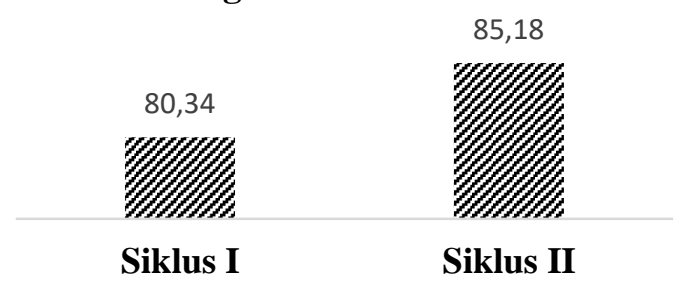

Gambar 1. Diagram Batang Peningkatan Keberhasilan Kegiatan Workshop

\section{2) Keaktifan Guru}

Gambaran keaktifan guru pada pelaksanaan tindakan siklus I dan siklus II mengalami peningkatan. Keaktifan guru dalam mengikuti kegiatan workshop akan berpengaruh kecepatan guru dalam menyelesaikan tugas dan kualitas hasil media pembelajaran. Guru yang aktif terlihat dari disiplin, motivasi, tanggung jawab, ketekunan, ketelitian, kemampuan bekerja sama, dan kreatifitas dalam menyelesaian tugas. Tabel 4 di bawah ini menunjukkan kecenderungan peningkatan skor keaktifan guru.

Tabel 4. Peningkatan Keaktifan Guru

\begin{tabular}{ccccccccc}
\hline \multirow{2}{*}{ No } & Kegiatan & Skor & Skor & Skor & \multicolumn{2}{c}{ Guru belum aktif } & \multicolumn{2}{c}{ Guru aktif } \\
\cline { 7 - 9 } & Workshop & Terendah & Tertinggi & Rata-rata & $\sum$ & \% & $\sum$ & \% \\
\hline 1 & Siklus I & 71,43 & 89,29 & 78,34 & 13 & 41,94 & 18 & 58,06 \\
2 & Siklus II & 75,00 & 92,86 & 82,29 & 6 & 19,35 & 25 & 80,65 \\
\hline
\end{tabular}

Berdasarkan tabel 4 di atas dapat dilihat bahwa keaktifan guru mengalami peningkatan, pada siklus I skor terendah 71,43 sedangkan skor rata-rata 78,34. Kondisi ini terjadi karena ada 13 guru yang belum aktif dalam kegiatan pembuatan media pembelajaran, terutama belum tampak memiliki motivasi yang tinggi. Ada beberapa guru juga masih tampak kesulitan dalam memahami materi workshop. Pada siklus II skor terendah 75,00 sedangkan skor rata-rata 82,29. Kondisi ini terjadi karena guru yang sudah aktif dalam kegiatan pembuatan media pembelajaran sebanyak 25 guru (80,65\%). Pada siklus II pemateri memberikan motivasi kepada peserta workshop agar memiliki rasa percaya diri dan semangat untuk belajar serta yakin mampu menyelesaikan tugasnya. Keterampilan membuat media pembelajaran berbasis Lectora Inspire 17 merupakan bagian dari kompetensi pedagogik yang harus terus ditingkatkan. Fungsi media pembelajaran sangat penting yaitu menjadikan kegiatan pembelajaran yang menyenangkan bagi siswa, sehingga meningkatkan prestasi akademik siswa. Media pembelajaran merupakan hasil karya guru yang dapat dinilaikan pada pengajuan angka kredit. Skor rata-rata keaktifan guru pada siklus I adalah 78,34 dan siklus II sebesar 82,29. Terjadi peningkatan skor rata-rata sebesar 3,95. Pada siklus I jumlah guru yang telah mencapai skor minimal 76,00 sebanyak 18 guru dan siklus II menjadi 25 guru, mengalami peningkatan sebanyak 7 orang. Kondisi ini terjadi karena kesadaran guru terhadap pengembangan kompetensi pedagogik, sehingga memiliki tanggung jawab, ketekunan, ketelitian, kemampuan bekerja sama, dan kreatifitas dalam membuat media pembelajaran. Persentase guru yang mencapai skor minimal 76,00 pada siklus II adalah $80,65 \%$ dari 31 orang guru. Keberhasilan untuk peningkatan keaktifan guru-guru sebesar $80 \%$ sudah tercapai pada siklus II dengan pencapaian $80.65 \%$. Dari tabel 4 di atas dapat ditampilkan keaktifan guru dalam pembuatan media pembelajaran berbasis Lectora Inspire 17 pada siklus I dan siklus II sebagai diagram batang di bawah ini. 
Tingkat Keaktifan Guru

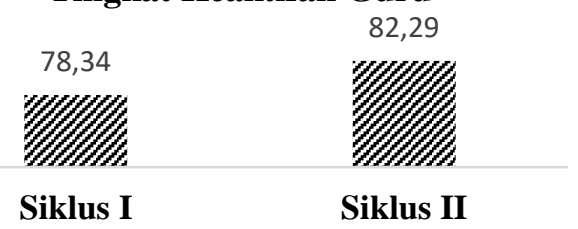

Gambar 2. Diagram Batang Keaktifan Guru

\section{3) Aspek Keterampilan Guru}

Keterampilan guru dalam pembuatan media pembelajaran berbasis Lectora Inspire 17 mengalami peningkatan selama pelaksanaan tindakan siklus I dan siklus II. Pengembangan keterampilan guru berfungsi untuk melatih ketelitian dan keterampilan, mengembangkan fantasi dan kreativitas, untuk melatih motorik halus memupuk pengamatan, pendengaran dan daya pikir, mengembangkan perasaan estetis, melatih daya ingat, mengembangkan imajinasi, melatih kerja sama dan tenggang rasa dengan teman. Tabel berikut menunjukkan kecendrungan peningkatan skor keterampilan guru.

Tabel 5. Peningkatan Keterampilan Guru

\begin{tabular}{ccccccccc}
\hline \multirow{2}{*}{ No } & $\begin{array}{c}\text { Kegiatan } \\
\text { Workshop }\end{array}$ & $\begin{array}{c}\text { Skor } \\
\text { Terendah }\end{array}$ & $\begin{array}{c}\text { Skor } \\
\text { Tertinggi }\end{array}$ & $\begin{array}{c}\text { Skor } \\
\text { Rata-rata }\end{array}$ & \multicolumn{2}{c}{ Guru belum terampil } & \multicolumn{2}{c}{ Guru terampil } \\
\hline 1 & Siklus I & 69,12 & 85,29 & 77,51 & 12 & \% & $\sum$ & \% \\
\hline & Siklus II & 75,00 & 91,18 & 81,36 & 4 & 12,90 & 27 & 61,29 \\
& & & &
\end{tabular}

Berdasarkan tabel 5 di atas dapat dilihat bahwa keterampilan guru mengalami peningkatan, pada siklus I skor terendah 69,12 sedangkan skor rata-rata 77,51. Kondisi ini terjadi karena ada 12 guru yang belum terampil dalam pembuatan media pembelajaran, yaitu belum mampu menyelesaikan media pembelajaran. Ada beberapa guru juga masih tampak kesulitan dalam memahami materi workshop. Pada siklus II skor terendah 75,00 sedangkan skor rata-rata 81,36. Kondisi ini terjadi karena guru yang sudah terampil dalam pembuatan media pembelajaran sebanyak 27 guru $(87,10 \%)$. Keterampilan membuat media pembelajaran adalah kecakapan menggunakan alat dan media melalui kegiatan praktik yang bersifat intelektual dan fisik untuk menghasilkan sesuatu yang lebih bernilai dalam waktu lebih cepat. Dengan berbagai contoh dan berulang kali latihan dapat mengembangkan keterampilan, yang berfungsi untuk melatih ketelitian, kreatifitas, daya ingat dan sebagainya. Pada siklus II dibuat kelompok yang beranggotakan 5-7 guru dengan satu fasilitator, sehingga pembimbingan lebih fokus. Selain itu waktu untuk menyelesaikan tugas juga lebih lama sehingga guru memiliki kesempatan untuk berulang kali latihan dan mengembangkan keterampilan. Skor rata-rata produk pada siklus I adalah 77,51 dan siklus II sebesar 81,36. Terjadi peningkatan skor rata-rata sebesar 3,85. Pada siklus I jumlah guru yang telah mencapai skor minimal 76,00 sebanyak 19 guru dan siklus II menjadi 27 guru, mengalami peningkatan sebanyak 8 orang. Kondisi ini terjadi karena guru sudah memiliki keterampilan dalam membuat media pembelajaran. Persentase guru yang mencapai skor minimal 76,00 pada siklus II adalah $87,10 \%$. Keberhasilan guru dalam membuat media pembelajaran sebesar $80 \%$ sudah tercapai pada siklus II dengan pencapaian 87.10\%. Dari tabel 5 di atas dapat ditampilkan keberhasilan guru dapat media pembelajaran berbasis Lectora Inspire 17 pada siklus I dan siklus II sebagai diagram batang di bawah ini.

\section{Penilaian Media Pembelajaran}



Gambar 3. Diagram Penilaian Media Pembelajaran

\section{SIMPULAN DAN SARAN}

Berdasarkan hasil penelitian tindakan sekolah yang telah dilaksanakan maka dapat dibuat simpulan sebagai berikut: 1) Melalui workshop dapat meningkatkan keterampilan guru dalam membuat media pembelajaran berbasis Lectora Inspire 17. Hal tersebut ditunjukkan dengan peningkatan keterampilan guru dalam membuat media pembelajaran berbasis Lectora Inspire 17 dari kondisi pra tindakan, siklus I dan siklus II. Kondisi pra tindakan, dari 31 guru hanya 8 guru yang memiliki keterampilan membuat media pembelajaran dan 23 guru belum terampil membuat media pembelajaran. Setelah tindakan siklus I, jumlah guru yang terampil membuat media pembelajaran berbasis Lectora Inspire 17 (skor minimal 76) menjadi sebanyak 19 guru $(61,29 \%)$. Selanjutnya setelah tindakan siklus II, jumlah guru yang terampil membuat media pembelajaran berbasis Lectora Inspire 17 (skor minimal 76) menjadi sebanyak 27 guru $(87,10 \%)$. 2) Kegiatan workshop di SMK Negeri 1 Pajangan dilaksanakan dengan baik sehingga dapat 
meningkatkan keterampilan guru dalam pembuatan media pembelajaran berbasis Lectora Inspire 17 dengan langkah-langkah sebagai berikut : a) Tahap perencanaan yaitu: (1) menyusun Term Of Reference, rencana anggaran dan jadwal workshop, menyiapkan program aplikasi Lectora Inspire 17, dan mencetak bahan ajar; (2) Membuat lembar observasi kegiatan workshop, lembar observasi keaktifan guru, lembar penilaian media pembelajaran, undangan dan daftar hadir nara sumber serta peserta workshop; (3) Berkoordinasi secara aktif dengan teman sejawat yang akan membantu pelaksanaan workshop; (4) Menyiapkan laboratorium komputer dan perlengkapannya sebagai tempat workshop. b) Tahap pelaksanaan workshop yaitu: (1) Membuka kegiatan, menjelaskan tujuan workshop, pembagian bahan ajar, menginstal program aplikasi Lectora Inspire 17 pada komputer yang digunakan oleh peserta; (2) Pemateri menerangkan teori tentang cara dan praktik langkah - langkah pembuatan media pembelajaran berbasis Lectora Inspire 17, setiap guru langsung praktik membuat media pembelajaran berbasis Lectora Inspire 17 dengan cara mengikuti langkah-langkah yang disampaikan pemateri. Setiap guru melanjutkan pembuatan media pembelajaran dengan kerja individu dan diperbolehkan untuk bekerja sama dengan guru yang lain; (3) Selama kegiatan workshop dilakukan observasi terhadap kegiatan workshop menggunakan lembar observasi kegiatan workshop dan dilakukan observasi terhadap keaktifan guru menggunakan lembar observasi keaktifan guru. c) Tahap evaluasi yaitu: menilai hasil media pembelajaran yang dibuat oleh masing-masing guru dengan menggunakan lembar penilaian produk.

Berdasarkan hasil yang diperoleh dalam penelitian ini, beberapa saran yang perlu dipertimbangkan kepada pihak-pihak yang terkait dengan upaya peningkatan mutu pendidik yaitu: 1) Para Kepala Sekolah, untuk meningkatkan kompetensi pedagogik khususnya keterampilan membuat media pembelajaran berbasis program aplikasi yang mudah di down load dari internet, sehingga sekolah memiliki banyak jenis media pembelajaran interaktif. Dengan harapan kegiatan pembelajaran semakin berkualitas sehingga prestasi akademik siswa semakin tinggi. 2) Para Pengawas Pendidikan, bahwa peningkatan mutu pendidik bukan suatu hal yang sederhana. Perlu upaya berkelanjutan untuk melaksanakan supervisi, agar pola pembelajaran guru-guru SMK sesusai dengan Peraturan Menteri Pendidikan dan Kebudayaan No.34 tahun 2018. 3) Para guru, media pembelajaran berbasis program aplikasi memiliki beberapa keunggulan untuk memberikan motivasi siswa dan memudahkan penyampaian materi kepada siswa. Media pembelajaran berbasis Lectora Inspire 17 dilengkapi dengan fitur pembuatan evaluasi, jika menggunakan fitur evaluasi ini siswa dan guru langsung bisa mengetahui nilainya.

\section{DAFTAR PUSTAKA}

Aditya Bakti. Heinich, Robert, Michael Molenda, James D. Russel, (1982). Instructional Media and the New Technology of Instruction. New York: Jonh Wily and Sons.

Ahmad Amrullaah, Zainal Aqib. (2017). Penelitian Tindakan Sekolah. Yogyakarta: Andi

Arief S, Sadiman, Drs, dkk (2005). Media Pendidikan. Jakarta: Raja Grafindo Persada

Arikunto, S., Suhardjono, Supardi. (2019). Penelitian Tindakan Kelas. Jakarta: Bumi Aksara.

Corinorita. 2016. Pelaksanaan In House Training untuk Meningkatkan Kompetensi Guru dalam Menyusun RPP di Sekolah Menengah Pertama. Jurnal Ilmu Pendidikan Sosial, Sains, dan Humaniora Vol. 3 No. 1, Maret 2017.

Jam'an, Satori. (2013) Profesi Keguruan. Universitas Terbuka. Jakarta: 2013

Rosmayanti, H.P. (2010). Mengenal ilmu komunikasi. Bandung: Widya padjajaran

Sa'bani, F. (2017). Peningkatan Kompetensi Guru dalam Menyusun RPP melalui Kegiatan Pelatihan pada MTs Muhammadiyah Wonosari. Jurnal Pendidikan Madrasah, Volume 2, Nomor 1, Mei 2017

Sahertian, Pieter. (2010). Perilaku Kepemimpinan Berorientasi Hubungan Dan Tugas Sebagai Anteseden Komitmen Organisasional, SelfEfficacy Dan Organizational Citizenship Behavior (OCB). Jurnal manajemen dan kewirausahaan, vol.12, no. 2, 156-169.

Suciati (2013) Belajar dan Pembelajaran. Universitas Terbuka. Jakarta: 2013

Sugiyono, DR. (2018). Metode Penelitian Kuantitatif Kualitatif dan RD. Bandung: Alfabeta

Widia, Pekerti, dkk. (2012). Metode Pengembangan Seni. Jakarta: Universitas Terbuka.

(2009). Peraturan Menteri Negara Pendayagunaan Aparatur Negara dan Reformasi Birokrasi Nomor 16 Tahun 2009, Tentang Jabatan Fungsional Guru dan Angka Kreditnya. Jakarta: 2009

(2007). Permendiknas Nomor 16 Tahun 2007 Tentang Standar Kualifikasi Akademik dan Kompetensi Guru. Jakarta: 2007 